\title{
HUBUNGAN PENGUASAAN DIKSI DENGAN KEMAMPUAN MENULIS PUISI SISWA KELAS IX SMP NEGERI 4 BALIGE TAHUN PEMBELAJARAN 2016/2017
}

\author{
Oleh \\ Kartini Simorangkir \\ Dra. Rosdiana Siregar, M.Pd.
}

\begin{abstract}
ABSTRAK
Penelitian ini bertujuan untuk mengetahui hubungan penguasaan diksi dengan kemampuan menulis puisi siswa kelas IX SMP Negeri 4 Balige Tahun Pembelajaran 2016/2017. Populasi penelitian ini adalah seluruh siswa kelas IX SMP Negeri 4 Balige tahun pembelajaran 2016/2017 yang terdiri dari enam kelas dengan jumlah 165 siswa. Sampel penelitian sebanyak 33 siswa yang diambil secara acak. Metode yang digunakan adalah metode deskriptif korelasional. Data penguasaan diksi dijaring dengan tes objektif pilihan berganda dan kemampuan menulis puisi dijaring dengan tes penugasan. Sebelum pengujian hipotesis terlebih dahulu dilakukan uji persyaratan analisis yaitu normalitas, linearitas dan keberartian.Dari pengolahan data, diketahui tingkat penguasaan diksi siswa kelas IX SMP Negeri 4 Balige Tahun Pembelajaran 2016/2017 tergolong baik dengan nilai rata-rata 74,84 . Kemampuan menulis puisi oleh siswa kelas IX SMP Negeri 4 Balige Tahun Pembelajaran 2016/2017 tergolong baik dengan nilai rata-rata 81,18. Perhitungan koefisien korelasi didapat $r=0,811$ dan indeks determinasi $\mathrm{I}=65 \%$, artinya ada korelasi yang positif dan berarti antara penguasaan diksi dengan kemampuan menulis puisi, dimana 65\% dari kemampuan menulis puisi siswa merupakan sumbangan dari penguasaan diksi. Selanjutnya, pengujian hipotesis dengan menggunakan korelasi product moment diperoleh nilai $\mathrm{r}_{\text {hitung }}=0,811$ dan nilair $\mathrm{r}_{\text {tabel }}$ pada tarafsignifikansi $\alpha=0,05$ dengan $\mathrm{N}=33$ sebesar 0,344 menunjukkan bahwa $\mathrm{r}_{\text {hitung }}>\mathrm{r}_{\text {tabel }}$ yaitu $0,811>0,344$ sehingga hipotesis penelitian diterima. Sehingga dapat disimpulkan bahwa ada hubungan yang signifikan antara penguasaan diksi dengan kemampuan menulis puisi siswa kelas IX SMP Negeri 4 Balige tahun pembelajaran 2016/2017.
\end{abstract}

Kata Kunci : Penguasaan diksi, Menulis puisi

\section{PENDAHULUAN}

Pembelajaran bahasa Indonesia memiliki empat aspek keterampilan berbahasa yakni menyimak, berbicara, membaca, dan menulis. Dibandingkan dengan tiga keterampilan berbahasa yang lain, keterampilan menulis lebih sulit dikuasai. Hal ini disebabkan keterampilan menulis menghendaki penguasaan berbagai unsur, baik unsur kebahasaan maupun unsur isi. Menulis merupakan salah satu aspek keterampilan 
berbahasa yang dipergunakan untuk berkomunikasi secara tidak langsung dan tidak secara tatap muka dengan orang lain. Secara tidak langsung menulis adalah bentuk komunikasi yang kita lakukan melalui bahasa tulis. Hanya saja menulis memerlukan proses dan tahapan tertentu sehingga menghasilkan sebuah tulisan.

Kamus Besar Bahasa Indonesia (Barus, 2010:1), "Menulis adalah aktivitas berbahasa yang produktif, ekspresif, dan tidak lansung atau tidak tatap muka. Kemudian Barus (2010:1) menyatakan "Menulis adalah rangkaian kegiatan mengungkapkan dan menyampaikan gagasan atau pikiran kepada pembaca agar pembaca dapat memahaminya." Dari pengertian tersebut diperoleh bahwa dalam mencapai kesuksesan berkomunikasi dengan menulis, penulis harus mampu mengungkapkan dan menyampaikan gagasannya dengan menggunakan pilihan kata yang efektif dan efisien. Sebagai suatu keterampilan berbahasa, menulis merupakan kegiatan yang kompleks karena penulis dituntut untuk dapat menyusun dan mengorganisasi isi tulisan serta menuangkannya dalam ragam bahasa tulis. Melalui kegiatan menulis, seseorang akan mampu mengungkapkan pikiran, ide, dan gagasan kepada orang lain baik dalam bentuk ilmiah seperti jurnal maupun makalah ataupun bentuk sastra seperti novel, cerpen, puisi, dan drama.

Sastra merupakan komponen dari pengajaran bahasa Indonesia. Menyampaikan ide-ide kreatif melalui karya sastra seperti novel, cerpen, puisi, dan drama termasuk dalam kompetensi yang harus dicapai siswa yaitu pada Kompetensi Dasar 16.1 Menulis puisi bebas dengan mengguna-kan pilihan kata yang sesuai. Dari berbagai bentuk karya sastra tersebut, peneliti tertarik pada pengajaran menulis puisi. Melalui menulis puisi, siswa dapat menyampaikan ide kreatif serta imajinasi yang ada dalam pikiran mereka kedalam bahasa yang indah melalui seni merangkai kata-kata yang penuh makna.

Ambarita dalam bukunya menyatakan bahwa menulis puisi merupakan suatu keterampilan yang bukan berdasarkan pengamatan sepintas hanya menyediakan tema yang akan diteruskan oleh siswa melainkan dapat diperoleh dengan memunculkan ide - ide kreatif yang bersumber dari pengalamanKemampuan menulis puisi tidak dapat muncul begitu saja tanpa adanya teori dan latihan secara rutin yang dilakukan oleh siswa. Agar mencapai hasil yang tinggi dalam menulis puisi, siswa harus meningkatkan latihan menulis puisi. Apabila kemampuan menulis siswa tidak 
ditingkatkan maka kemampuan siswa dalam menuangkan ide melalui kegiatan menulis puisi berkurang.

Pengalaman saya selama masa PPL (Praktek Pengalaman Lapangan), siswa terlihat kurang menyukai pembelajaran menulis puisi. Itu dikarenakan siswa kesulitanmenciptakan ataupun memilih kata yang tepat untuk membuat puisi itu terlihat indah dan penuh makna.Ketika satu kelas disuruh membuat puisi bertema alam, dari 30 orang siswa hanya 10 orang yang dapat membuat puisi dengan bahasa yang indah, siswa lainnya kurang memiliki minat dalam menulis puisi. Hal ini juga diperkuat oleh hasil wawancara penulis dengan guru bidang studi Bahasa Indonesia di SMP Negeri 4 Balige, Ibu Delfi Purba. Beliau menyatakan bahwa siswa siswanya tidak memiliki minat dalam menulis puisi. Itu disebabkan oleh kebanyakan siswa kesulitan memilih kata yang tepat dalam menuangkan ide dan imajinasi mereka ke dalam puisi. Hal ini diperkuat dengan ketercapaian hasil menulis siswa yang tidak mencapai nilai KKM yaitu 80. Nilai rata-rata yang mereka peroleh dalam pembelajaran menulis puisi adalah 75 . Siswa mengatakan bahwa mereka tidak mampu menggunakan kata-kata yang indah penuh makna. Guru juga mengatakan karena penguasaan kosakata yang kurang sehingga pemilihan diksi pun berkurang disebabkan kuantitas kebiasaan membaca siswa yang kurang.

Penelitian yang dilakukan oleh Jumariah (2012:69) berjudul "Pengaruh Penguasaan Diksi Dan Minat Membaca Puisi Terhadap Kemampuan Menulis Puisi Siswa Kelas X SMA Swata Melati Tandam Hilir II Kecamatan HamparanPerak Tahun Pembelajaran 2011/2012" menjelaskan bahwa penguasaan diksi dan maknanya pada siswa cenderung cukup dengan nilai rata-rata 66,56.

Ketidakmampuan siswa dalam menulis puisi juga diungkapkan oleh Ningsih (2013 : 63) yang berjudul "Pengaruh Metode Karyawisata terhadap Kemampuan Menulis Puisi Siswa Kelas X Madrasah Aliyah Negeri 2 Tanjung Pura Tahun pembelajaran 2012/2013" pada penelitian tersebut disimpulkan bahwa menulis puisi siswa di sekolah tersebut diperoleh tes awal 61,90 dan tes akhir 72,96. Kekurangmampuan ini juga disebabkan oleh beberapa faktor diantaranya adalah rendahnya penguasaan terhadap diksi.

Penelitian dilakukan Perangin-angin (2013 : 56) berjudul "Hubungan Penguasaan Diksi dan Gaya Bahasa Terhadap Kemampuan Menulis Puisi Siswa kelas X SMA 
Negeri 1 Berastagi Tahun Pembelajaran 2012/2013" menyatakan bahwa kemampuan penguasaan diksi siswa cenderung cukup. Siswa mendapat nilai dengan rata-rata 65,725 .

Rendahnya hasil pembelajaran menulis puisi juga dilakukan Angraini (2014 : 63) yang berjudul "Peningkatan Kemampuan Menulis Puisi Menggunakan Model Sugestopedia pada Siswa Kelas X SMA Swasta Parulian 2 Tahun Pembelajaran 2014/2015" mengatakan bahwa kemampuan siswa dalam menulis puisi perlu peningkatan dan rutinitas melakukan latihan demi mencapai hasil yang memuaskan. Hal ini diperkuat dengan ketercapaian hasil menulis siswa yang tidak mencapai nilai KKM yaitu 72 dengan skor rata - ratakemampuan menulis puisi siswa adalah 50. Melihat hasil kemampuan siswa tersebut, maka perlu ditumbuhkan minat dalam menulis puisi. Karena minat merupakan suatu hal yang dapat memacu siswa menulis puisi.

Kemampuan siswa dalam menulis puisi masih tergolong cukup. Hal ini didukung oleh hasil penelitian Dalimunthe (2006) dalam skripsinya "Kemampuan menulis puisi dengan memanfaatkan wacana sebagai sumber inspirasi pada Siswa Kelas VII SLTP Swasta Sutini Medan tahun pembelajaran 2004/2005", yang menyatakan hasil kemampuan menulis puisi siswa yang terinspirasi dari wacana tergolong cukup dengan skor rata - rata 61,67 .

Puisi adalah perasaan imajinatif yang dituang kedalam rangkaian kata- kata penuh makna. Ketika siswa dapat menuliskan puisi dengan menarik, maka siswa telah mampu menuangkan imajinasi dan perasaan mereka kedalam puisi. Hal inilah yang yang dituntut oleh Kurikulum Tingkat Satuan Pendidikan (KTSP). Semakin tinggi kosakata yang dikuasai siswa, maka pemilihan katanya juga akan semakin baik. Dalam menulis puisi, siswa perlu menambah kosakata yang dimilikinya agar pemilihan kata-kata dalam menulis puisi pun menjadi lebih baik. Oleh karena itu, puisi yang dihasilkan menjadi lebih baik.

Pemilihan kata pada puisi sangat menentukan kejelasan bahasa dalam karya puisi dan memberi warna dalam puisi tersebut. Penggunaan diksi yang baik dapat membuat puisi lebih menarik bahkan dapat menyentuh hati si pembacanya. Sesuai dengan pernyataan Situmorang (Ambarita, 2010:5) bahwa bahasa puisi itu haruslah sama sekali jelas, kuat, jitu, dan menarik. Dan juga kita ketahui bahwa kata-kata dalam puisi tersebut mempunyai makna, ada yang bermakna kias, ada yang bermakna lambang, ada 
yang bermakna konkret, ada yang bermakna konotasi dan denotasi, menggunakan gaya bahasa, dan memperhatikan rima dan pengimajian. Hubungan beberapa unsur ini harus baik. jadi penelitian ini hanya dibatasi pada beberapa unsur tersebut.

Berangkat dari permasalahan tersebut, kurangnya penguasaan siswa tentang diksi akan mengurangi minat siswa dalam menulis puisi. Diksi telah menjadikan puisi menjadi karya sastra yang indah dan menjadi ungkapan hati dari penulisnya. Hal ini juga dikemukakan oleh Gani dalam Ambarita (2010 :3) "Pilihan kata atau diksi merupakan unsur yang paling penting dalam penulisan sebuah puisi, dalam pengertian bahwa pilihan kata adalah seni utama dalam penulisan puisi."

\section{METODE PENELITIAN}

Metode merupakan bagian yang penting dalam suatu pelaksanaan penelitian. Metode yang digunakan dalam peneltian ini adalah metode deskriptif korelatif. Metode deskriptif korelatif adalah suatu cara atau teknik yang mengungkapkan fakta yang jelas tentang gejala-gejala serta hubungan yang ada pada suatu objek penelitian.Penelitian ini bertujuan untuk membuktikan apakah ada kontribusi yang signifikan antara penguasaan diksi dengan kemampuan menulis puisi siswa kelas IX SMP Negeri 4 Balige tahun pembelajaran 2016/2017. Hal ini sejalan dengan pendapat Arikunto (2013: 313) yang mengatakan "Penelitian korelasi bertujuan untuk menemukan ada tidaknya kontribusi, apabila ada berapa eratnya serta berarti atau tidaknya kontribusi itu." Jadi metode deskriptif korelatif ini digunakan bertujuan untuk mengetahui hubungan antara penguasaan diksi dengan kemampuan menulis puisi.

Data yang diperoleh selanjutnya dianalisis secara statistik dengan langkahlangkah analisis yaitu data hasil variabel (X) disusun dalam bentuk tabel, menentukan nilai rata-rata dan standar deviasi dari kedua data sampel, menghitung uji normalitas, uji linieritas dan keberartian, danuji hipotesis. Setelah t diketahui maka nilai tersebut akan dikonsultasikan dengan tabel pada taraf signifikansi 5\% dengan derajat kebebasan (dk) $=\mathrm{n}-1$ pada taraf nyata $\alpha=0,05$. Dengan demikian, jika $\mathrm{t}_{0}<\mathrm{t}_{\mathrm{t}}$ pada taraf nyata $\alpha=0,05$ maka Ho diterima dan Ha ditolak sebaliknya jika $t_{0}>t_{t}$ pada taraf nyata $\alpha=0,05$ maka Ho ditolak dan Ha diterima. Perhitungan berapa besarnya kontribusi dengan menggunakan $\mathrm{KP}=\mathrm{r}^{2} \times 100 \%$. 


\section{HASIL PENELITIAN DAN PEMBAHASAN}

\section{Hasil Penelitian}

\section{a. Penguasaan Diksi}

Penguasaan diksi oleh siswa kelas IX SMP Negeri 4 Balige tahun pembelajaran 2016/2017 memeperoleh nilai rata-rata sebesar 74,84dan simpangan baku atau standard deviasi sebesar 6,72. Skor tertinggi penguasaan diksi (X) adalah 90 dan skor terendah adalah 55.Siswa yang mendapat kategori baik sebanyak 63\%, kategori cukup sebanyak $31 \%$, kategori kurang 6\%. Dengan demikian dapat disimpulkan bahwa yang memiliki persentase terbaik adalah kategori baik. Dengan demikian dapat disimpulkan bahwa yang memiliki persentase terbaik adalah kategori baik, sehingga penguasaan diksi tahun pemebelajaran 2016/2017 cenderung baik.

\section{b. Kemampuan Menulis Puisi Siswa}

Kemampuan menulis puisi siswa kelas IX SMP Neger 4 Balige tahun pembelajaran 2016/2017 dengan nilai rata - rata yang diperoleh adalah 81,18. skor tertinggi kemampuan menulis pusi (Y) adalah 90 dan skor terendah adalah 60dan simpangan baku atau standard deviasi sebesar 7,98.Kemampuan menulis puisi dapat dikategorikan menjadi 3 kategori yaitu sangat baik 48\%, baik 36\%, dan kategori cukup 9\%. Hasil nilai tersebut menunjukkan bahwa, Kemampuan menulis puisi siswa kelas IX SMP Negeri 4 Balige tahun pembelajaran 2016/2017 termasuk dalam kategori baik.

\section{c. Hubungan Penguasaan Diksi dengan Kemampuan Menulis Puisi Siswa}

Berdasarkan hasil uji korelasi product moment diperoleh $r_{\text {hitung }}=0,811$ jika dibandingkan dengan $r_{\text {tabel }}$ pada tingkat kepercayaan $95 \%$ sebesar 0,344 menunjukkan bahwa $r_{\text {hitung }}>r_{\text {tabel }}$. Hal tersebut berarti Ha diterima yang menyatakan bahwa ada hubungan yang signifikan antara penguasaan diksi dengan kemampuan menulis puisi. Dari hasil perhitungan indeks determinasi tersebut, maka diketahui besar sumbangan penguasaan diksi siswa adalah sebesar $65 \%$ dan sisanya ditentukan faktor - faktor lain. Hasil tersebut cukup sinkron dengan kerangka teoretis maupun kerangka konseptual yang secara ringkas dinyatakan bahwa ada hubungan antara penguasaan diksi dengan kemampuan menulis puisi. 


\section{Pembahasan Hasil Penelitian}

\section{a. Kemampuan Penguasaan Diksi}

Tingkat penguasaan diksi pada siswa kelas IX SMP Negeri 4 Balige Tahun Pembelajaran 2016/2017 termasuk dalam kategori baik dengan nilai rata-rata 74,84. Siswa yang mendapat kategori baik sebanyak 63\%, kategori cukup sebanyak $31 \%$, kategori kurang 6\%. Dikatakan baik karena peneliti menilai semakin sering siswa dilatih penguasaan kosakatanya dalam berbicara ataupun menulis maka penguasaan kosakata siswa akan meningkat dan pemilihan diksinya semakin baik. Siswa menjadi lebih gemar membaca sehingga penguasaan kosakatanya menjadi semakin baik. Diksi merupakan unsur yang penting dalam penulisan sebuah puisi, dalam pengertian bahwa pilihan katalah seni utama penciptaan puisi (Gani, 1981:9). Kata-kata dalam puisi tersebut mempunyai makna, ada yang bermakna konkret, dan ini terjadi karena dalam puisi ada pengiasan, pengimajian, dan pelambangan.

\section{b. Kemampuan Menulis Puisi}

Tingkat penguasaan diksi pada siswa kelas IX SMP Negeri 4 Balige Tahun Pembelajaran 2016/2017 termasuk dalam kategori baik dengan nilai rata-rata 81,18. Dikatakan baik karena kontribusi dari penguasaan diksi yang baik pula. Seperti yang diungkapkan Gani (Ambarita,2010 :3) bahwa diksi atau pilihan kata merupakan unsur yang penting dalam penulisan sebuah puisi, dalam pengertian bahwa pilihan katalah seni utama penciptaan puisi.

Penguasaan diksi yang baik memudahkan siswa dalam membuat suatu puisi yang indah. Kata-kata yang digunakan dalam puisi ditempatkan secara hati-hati dalam puisi sehingga makna puisi terasa indah. Penguasaan diksi ini perlu diperhatikan karena semakin baik pemakaian diksi, maka semakin besar efek serta daya tarik puisinya. Penguasaan diksi semakin bertambah dengan seringnya siswa dituntun untuk gemar membaca dan menulis.

\section{c. Hubungan Penguasaan Diksi dengan Kemampuan Menulis Puisi}

Kemampuan siswa dalam menulis puisi dipengaruhi oleh beberapa faktor dan salah satu faktor dalam menulis puisi adalah penguasaan diksi. Setelah melakukan prosedur penelitian yang cukup panjang mulai dari uji normalitas hingga pengujian hipotesis, akhirnya mendapatkan hasil penelitian yang menunjukkan adanya hubungan yang signifikan antara penguasaan diksi dengan kemampuan menulis puisi. 
Berdasarkan data penelitian, nilai mereka sebagian mengalami penurunan yaitu nilai penguasaan diksi tinggi sementara nilai kemampuan menulis puisinya rendah. Namun dalam penelitian ini mengambil nilai keseluruhan. Jadi, secara umum nilai penguasaan diksi terhadap kemampuan menulis puisi siswa kelas IX SMP Negeri 4 Balige mengalami peningkatan.

Berdasarkan hasil uji korelasi product moment diperoleh $\mathrm{r}_{\text {hitung }}=0,811$ jika dibandingkan dengan $r_{\text {tabel }}$ pada tingkat kepercayaan 95\% sebesar 0,344 menunjukkan bahwa $r_{\text {hitung }}>r_{\text {tabel }}$. Hal tersebut berarti Ha diterima yang menyatakan bahwa ada hubungan yang signifikan antara penguasaan diksi dengan kemampuan menulis puisi.

Dari hasil perhitungan indeks determinasi tersebut, maka diketahui besar sumbangan penguasaan diksi siswa adalah sebesar $65 \%$ dan sisanya ditentukan faktor - faktor lain.Dengan demikian, adanya hubungan antara penguasaan diksi dengan kemampuan menulis puisi telah terbukti dari hasil penelitian terhadap siswa kelas IX SMP Negeri 4 Balige tahun pembelajaran 2016/2017.

Kemampuan siswa dalam menulis puisi juga baik jika dibarengi dengan penguasaan diksi yang baik pula. Diksi atau pilihan kata adalah alat untuk menampilkan gagasan dalam penciptaan puisi. Diksi memberi warna tersendiri dalam membangun puisi tesebut.

Pembelajaran menulis puisi bertujuan mengembangkan kearifan menangkap isyarat-isyarat kehidupan dan membangkitkan kegemaran membaca pada siswa. Oleh sebab itu penguasaan diksi perlu mendapat perhatian khusus bagi para pendidik untuk lebih ditingkatkan lagi agar pemeblajaran menulis puisi menjadi lebih baik lagi. Untuk itu, perlu diadaka penelitian lanjut mengenai hubungan penguasaan diksi dengan kemampuan menulis puisi untuk hasil yang lebih baik lagi.

\section{PENUTUP}

Penguasaan diksi oleh siswa kelas IX SMP Negeri 4 Balige Tahun Pembelajaran 2016/2017 adalah baik dengan skor rata-rata 74,84. Kemampuan menulis puisi siswa kelas IX SMP Negeri 4 Balige Tahun Pembelajaran 2016/2017 adalah baik dengan skor rata-rata 81,18 Sehingga terdapat hubungan yang signifikan antara penguasaan diksi dengan kemampuan menulis puisi siswa kelas IX SMP Negeri 4 Balige Tahun Pembelajaran 2016/2017. Hal ini terbukti dari hasil perhitungan korelasi product 
moment pada taraf signifikansi 5\% diperoleh nilai $r_{\text {hitung }}>r_{\text {tabel }}$ yakni 0,685 $>0,304$ dan nilai kontribusi sebesar $65 \%$ dengan kategori baik sedangkan sisanya dipengaruhi oleh faktor lain yang tidak diteliti dalam penelitian ini.

\section{DAFTAR PUSTAKA}

Angraini, Nina. 2014.Peningkatan Kemampuan Menulis Puisi Menggunakan Model Sugestopedia pada Siswa kelas X SMA Swasta Parulian 2 Medan Tahun Pembelajaran 2013/2014. Medan. Universitas Negeri Medan.

Arikunto, Suharsimi. 2013. Prosedur Penelitian Suatu Pendekatan Praktik. Jakarta: Rineka Cipta.

Ambarita, Biner. 2010. Berbagai Pendekatan dalam Pengajaran Bahasa dan Sastra Indonesia. Bandung : Alfabeta.

Barus, Sanggup. 2010. Pembinaan Kompetensi Menulis. Medan : USU Press.

Dalimunthe.2005. Kemampuan Menulis Puisi dengan Memanfaatkan Wacana Sebagai Sumber Inspirasi pada Siswa Kelas VII SMP Swasta Sutini Medan Tahun Pembelajaran 2004/2005. Medan. Universitas Negeri Medan.

Jamariah. 2012. Pengaruh Penguasaan Diksi dan Minat Membaca Puisi Terhadap Kemampuan Menulis Puisi Siswa Kelas X SMA Swasta Melati Tandam Hilir II Kecamatan Hamparan Perak Tahun Pembelajaran 2011/2012. Medan. Universitas Negeri Medan

Ningsih, Agus Surya. 2013.Pengaruh Metode Karyawisata terhadap Kemampuan Menulis Puisi Siswa Kelas X Madrasah Aliyah Negeri 2 Tanjung Pura Tahun Pembelajaran 2012/2013. Medan. Universitas Negeri Medan.

Peranginangin, Debora. 2013. Hubungan Penguasaan Diksi dan Gaya Bahasa Terhadap Kemampuan Menulis Puisi Siswa kelas X SMA Negeri 1 Berastagi Tahun Pembelajaran 2012/2013. Medan. Universitas Negeri Medan 